\title{
Earthworms and Vermiculture Biotechnology
}

\author{
A. A. Ansari $i^{1,2}$ and S. A. Ismail ${ }^{3}$ \\ ${ }^{1}$ Department of Biological Sciences, Faculty of Science \\ ${ }^{2}$ Kebbi State University of Science and Technology \\ ${ }^{3}$ Managing Director, Ecoscience Research Foundation \\ 1,2Nigeria \\ India
}

\section{Introduction}

Earthworms are terrestrial invertebrates belonging to the Order Oligochaeta, Class Chaetopoda, Phylum Annelida, which have originated about 600 million years ago, during the pre-Cambrian era (Piearce et al., 1990). Earthworms occur in diverse habitat, exhibiting effective activity, by bringing about physical and chemical changes in the soil leading to improvement in soil fertility. An approach towards good soil management, with an emphasis on the role of soil dwellers like earthworms, in soil fertility, is very important in maintaining balance in an ecosystem (Shuster et al., 2000).

The role of earthworms in soil formation and soil fertility is well documented and recognised (Darwin, 1881; Edwards et al., 1995; Kale, 1998; Lalitha et al., 2000). The main activity of earthworms involves the ingestion of soil, mixing of different soil components and production of surface and sub surface castings thereby converting organic matter into soil humus (Jairajpuri, 1993). Earthworms play an important role in the decomposition of organic matter and soil metabolism through feeding, fragmentation, aeration, turnover and dispersion (Shuster et al., 2000).

Earthworms were referred by Aristotle as "the intestines of earth and the restoring agents of soil fertility" (Shipley, 1970). They are biological indicators of soil quality (Ismail, 2005), as a good population of earthworms indicates the presence of a large population of bacteria, viruses, fungi, insects, spiders and other organisms and thus a healthy soil (Lachnicht and Hendrix, 2001).

The role of earthworms in the recycling of nutrients, soil structure, soil productivity and agriculture, and their application in environment and organic waste management is well understood (Edwards et al., 1995; Tomlin et al., 1995; Shuster et al., 2000; Ansari and Ismail, 2001a, b; Ismail, 2005; Ansari and Ismail, 2008; Ansari and Sukhraj, 2010).

\section{Ecological strategies of earthworms}

Lee (1985), recognised three main ecological groups of earthworms, based on the soil horizons in which the earthworms were commonly found i.e., litter, topsoil and sub soil. 
Bouché (1971, 1977), also recognised three major groups based on ecological strategies: the epigeics (Épigés), anecics (Anéciques) and endogeics (Éndogés). Epigeic earthworms live on the soil surface and are litter feeders. Anecic earthworms are topsoil species, which predominantly form vertical burrows in the soil, feeding on the leaf litter mixed with the soil. Endogeic earthworms preferably make horizontal burrows and consume more soil than epigeic or anecic species, deriving their nourishment from humus.

\subsection{Distribution of earthworms}

Earthworms occur all over the world, but are rare in areas under constant snow and ice, mountain ranges and areas almost entirely lacking in soil and vegetation (Edwards and Bohlen, 1996). Some species are widely distributed, which are called peregrine, whereas others, that are not able to spread successfully to other areas, are termed as endemic (Edwards and Lofty, 1972).

\subsection{Factors affecting earthworm distribution}

The distribution of earthworms in soil is affected by physical and chemical characters of the soil, such as temperature, $\mathrm{pH}$, moisture, organic matter and soil texture (Edwards and Bohlen, 1996).

\subsection{Temperature}

The activity, metabolism, growth, respiration and reproduction of earthworms are all influenced greatly by temperature (Edwards and Bohlen, 1996).

\section{$2.4 \mathrm{pH}$}

$\mathrm{pH}$ is a vital factor that determines the distribution of earthworms as they are sensitive to the hydrogen ion concentration (Edwards and Bohlen, 1996; Chalasani et al., 1998). $\mathrm{pH}$ and factors related to $\mathrm{pH}$ influence the distribution and abundance of earthworms in soil (Staaf, 1987). Several workers have stated that most species of earthworms prefer soils with a neutral $\mathrm{pH}$ (Jairajpuri, 1993; Edwards and Bohlen, 1996). There is a significant positive correlation between $\mathrm{pH}$ and the seasonal abundance of juveniles and young adults (Reddy and Pasha, 1993).

\subsection{Moisture}

Prevention of water loss is a major factor in earthworm survival as water constitutes $75-90 \%$ of the body weight of earthworms (Grant, 1955). However, they have considerable ability to survive adverse moisture conditions, either by moving to a region with more moisture (Valle et al., 1997) or by means of aestivation (Baker et al., 1992). Availability of soil moisture determines earthworm activity as earthworm species have different moisture requirements in different regions of the world. Soil moisture also influences the number and biomass of earthworms (Wood, 1974).

\subsection{Organic matter}

The distribution of earthworms is greatly influenced by the distribution of organic matter. Soils that are poor in organic matter do not usually support large numbers of earthworms (Edwards and Bohlen, 1996). Several workers have reported a strong positive correlation 
between earthworm number and biomass and the organic matter content of the soil (Doube et al., 1997; Ismail, 2005).

\subsection{Soil texture}

Soil texture influences earthworm populations due to its effect on other properties, such as soil moisture relationships, nutrient status and cation exchange capacity, all of which have important influences on earthworm populations (Lavelle, 1992).

\subsection{Effect of earthworms on soil quality}

Earthworms, which improve soil productivity and fertility (Edwards et al., 1995), have a critical influence on soil structure. Earthworms bring about physical, chemical and biological changes in the soil through their activities and thus are recognised as soil managers (Ismail, 2005).

\subsection{Effects on physical properties of soil}

Soil structure is greatly influenced by two major activities of earthworms:

1. Ingestion of soil, partial breakdown of organic matter, intimate mixing of these fractions and ejection of this material as surface or subsurface casts.

2. Burrowing through the soil and bringing subsoil to the surface.

During these processes, earthworms contribute to the formation of soil aggregates, improvement in soil aeration and porosity (Edwards and Bohlen, 1996). Earthworms contribute to soil aggregation mainly through the production of casts, although earthworm burrows can also contribute to aggregate stability since they are often lined with oriented clays and humic materials (Lachnicht and Hendrix; 2001). Most workers have agreed that earthworm casts contains more water-stable aggregates than the surrounding soil and by their activity influence both the drainage of water from soil and the moisture holding capacity of soil, both of which are important factors for plant productivity (Edwards and Bohlen, 1996; Lachnicht and Hendrix; 2001).

\subsection{Effect on chemical properties of soil}

Earthworms bring about mineralisation of organic matter and thereby release the nutrients in available forms that can be taken up by the plants (Edwards and Bohlen, 1996). Organic matter that passes through the earthworm gut is egested in their casts, which is broken down into much finer particles, so that a greater surface area of the organic matter is exposed to microbial decomposition (Martin, 1991). Earthworms have major influences on the nutrient cycling process in many ecosystems (Edwards and Bohlen, 1996). These are usually based on four scales (Lavelle and Martin, 1992):

1. during transit through the earthworm gut,

2. in freshly deposited earthworm casts,

3. in aging casts, and

4. during the long-term genesis of the whole soil profile.

Earthworms contribute nutrients in the form of nitrogenous wastes (Ismail, 2005). Their casts have higher base-exchangeable bases, phosphorus, exchangeable potassium and 
manganese and total exchangeable calcium. Earthworms favour nitrification since they increase bacterial population and soil aeration. The most important effect of earthworms may be the stimulation of microbial activity in casts that enhances the transformation of soluble nitrogen into microbial protein thereby preventing their loss through leaching to the lower horizons of the soil. C: $\mathrm{N}$ ratios of casts are lower than that of the surrounding soil (Bouché, 1983). Lee (1983) summarised the influence of earthworms on soil nitrogen and nitrogen cycling. According to him, nitrogenous products of earthworm metabolism are returned to the soil through casts, urine, mucoproteins and dead tissues of earthworms.

\section{Earthworms and microorganisms}

There is a complex inter-relationship between earthworms and microorganisms. Most of the species of microorganisms that occur in the alimentary canal of earthworms are the same as those in the soils in which the earthworms live. The microbial population in earthworm casts is greatly increased compared with the surrounding soil (Haynes, et al., 1999). Earthworm casts usually have a greater population of fungi, actinomycetes and bacteria and higher enzyme activity than the surrounding soil (Lachnicht and Hendrix, 2001). Microbial activity in earthworm casts may have an important effect on soil crumb structure by increasing the stability of the worm-cast-soil relative to that of the surrounding soil (Edwards and Bohlen, 1996). Earthworms are very important in inoculating soils with microorganisms. Many microorganisms in the soil are in a dormant stage with low metabolic activity, awaiting suitable conditions like the earthworm gut (Lachnicht and Hendrix, 2001) or mucus (Lavelle et al., 1983) to become active. Earthworms have been shown to increase the overall microbial respiration in soil, thereby enhancing microbial degradation of organic matter.

\section{Earthworms and plant growth}

Earthworms prepare the ground in an excellent manner for the growth of plants (Darwin, 1881). Darwin's findings that earthworms play a beneficial role in soil fertility that is important for plant growth have been acknowledged by many workers (Lee and Foster, 1991; Alban and Berry, 1994; Nooren et al., 1995; Decaens et al., 1999). Earthworms have beneficial effects on soil and many workers have attempted to demonstrate that these effects increase plant growth and yields of crops (Decaens et al., 1999; Lalitha et al., 2000;). Earthworms release substances beneficial to plant growth like auxins and cytokinins (Krishnamoorthy and Vajranabhaiah, 1986). The beneficial effect of earthworms on plant growth may be due to several reasons apart from the presence of macronutrients and micronutrients in vermicast and in their secretions in considerable quantities (Lalitha et al., 2000; Ismail, 2005). Reports suggest that certain metabolites produced by earthworms may be responsible for stimulating plant growth.

\section{Earthworms and land reclamation}

The success of land reclamation by conventional techniques is often limited by poor soil structure and low inherent soil fertility, and even in productive soils, a marked deterioration in the botanical composition of the sward can occur within a number of years (Hoogerkamp et al., 1983). A number of studies indicate that earthworms play an important part in 
improving reclaimed soils (Boyle et al., 1997; Butt, 1999). Some experiments on improving impoverished soils by stimulating earthworm populations have been reported (Butt et al., 1997). A successful introduction of earthworms in reclaimable soil could be achieved by overcoming factors like unfavorable moisture conditions, excessive fluctuation of surface temperature and lack of suitable food (Satchell, 1983).

\section{Earthworms and organic solid waste management}

In recent years, disposal of organic wastes from various sources like domestic, agriculture and industrial has caused serious environmental hazards and economic problems. Burning of organic wastes contributes tremendously to environmental pollution thus, leading to polluted air, water and land. This process also releases large amounts of carbon dioxide in the atmosphere, a main contributor to global warming together with dust particles. Burning also destroys the soil organic matter content, kills the microbial population and affects the physical properties of the soil (Livan and Thompson, 1997). It has been demonstrated that earthworms can process household garbage, city refuse, sewage sludge and waste from paper, wood and food industries (Kale et al., 1982; Muyima et al., 1994; Edwards and Bohlen, 1996; Ismail, 2005). In tropical and subtropical conditions Eudrilus eugeniae and Perionyx excavatus are the best vermicomposting earthworms for organic solid waste management (Kale, 1998). The use of earthworms in composting process decreases the time of stabilisation of the waste and produces an efficient bio-product, i.e., vermicompost.

Organic farming system is gaining increased attention for its emphasis on food quality and soil health. Vermicompost and vermiculture associated with other biological inputs have been actually used to grow vegetables and other crops successfully and have been found to be economical and productive (Ismail, 2005; Ansari and Ismail, 2008).In this regard, recycling of organic waste is feasible to produce useful organic manure for agricultural application. Compost is becoming an important aspect in the quest to increase productivity of food in an environmentally friendly way. Compost is becoming an important aspect in the quest to increase productivity of food in an environmentally friendly way. Vermicomposting offers a solution to tonnes of organic agro-wastes that are being burned by farmers and to recycle and reuse these refuse to promote our agricultural development in more efficient, economical and environmentally friendly manner. Both the sugar and rice industries burn their wastes thereby, contributing tremendously to environmental pollution thus, leading to polluted air, water and land. This process also releases large amounts of carbon dioxide in the atmosphere, a main contributor to global warming together with dust particles. Burning also destroys the soil organic matter content, kills the microbial population and affects the physical properties of the soil (Livan and Thompson, 1997). Therefore organic farming helps to provide many advantages such as; eliminate the use of chemicals in the form of fertilizers/pesticides, recycle and regenerate waste into wealth; improve soil, plant, animal and human health; and creating an ecofriendly, sustainable and economical bio-system models (Ansari and Ismail, 2001a).

\subsection{Vermitechnology}

Vermitechnology is the use of surface and subsurface local varieties of earthworm in composting and management of soil (Ismail, 2005). Darwin (1881) has made their activities the object of a careful study and concluded that it may be doubted if there are any other 
animals which have played such an important part in the history of the world as these lowly organized creatures'. It has been recognized that the work of earthworms is of tremendous agricultural importance. Earthworms along with other animals have played an important role in regulating soil processes, maintaining soil fertility and in bringing about nutrient cycling (Ismail, 1997). Earthworms have a critical influence on soil structure, forming aggregates and improving the physical conditions for plant growth and nutrient uptake. They also improve soil fertility by accelerating decomposition of plant litter and organic matter and, consequently, releasing nutrients in the form that are available for uptake by plants.

\subsection{Vermicomposting}

Vermicomposting is the biological degradation and stabilization of organic waste by earthworms and microorganisms to form vermicompost. This is an essential part in organic farming today. It can be easily prepared, has excellent properties, and is harmless to plants. The earthworms fragment the organic waste substrates, stimulate microbial activity greatly and increase rates of mineralization. These rapidly convert the waste into humus-like substances with finer structure than thermophilic composts but possessing a greater and more diverse microbial activity. Vermicompost being a stable fine granular organic matter, when added to clay soil loosens the soil and improves the passage for the entry of air. The mucus associated with the cast being hydroscopic absorbs water and prevents water logging and improves water-holding capacity. The organic carbon in vermicompost releases the nutrients slowly and steadily into the system and enables the plant to absorb these nutrients. The soil enriched with vermincompost provides additional substances that are not found in chemical fertilizers (Kale, 1998). Vermicomposting offers a solution to tonnes of organic agro-wastes that are being burned by farmers and to recycle and reuse these refuse to promote our agricultural development in more efficient, economical and environmentally friendly manner. The role of earthworms in organic solid waste management has been well established since first highlighted by Darwin (1881) and the technology has been improvised to process the waste to produce an efficient bio-product vermicompost (Kale et al., 1982; Ismail, 1993, Ismail, 2005). Epigeic earthworms like Perionyx excavatus, Eisenia fetida, Lumbricus rubellus and Eudrilus eugeniae are used for vermicomposting but the local species like Perionyx excavatus has proved efficient composting earthworms in tropical or subtropical conditions (Ismail, 1993; Kale, 1998). The method of vermicomposting involving a combination of local epigeic and anecic species of earthworms (Perionyx excavatus and Lampito mauritii) is called Vermitech (Ismail, 1993; Ismail, 2005). The compost prepared through the application of earthworms is called vermicompost and the technology of using local species of earthworms for culture or composting has been called Vermitech (Ismail, 1993). Vermicompost is usually a finely divided peat-like material with excellent structure, porosity, aeration, drainage and moisture holding capacity (Edwards, 1982, 1988). The nutrient content of vermicompost greatly depends on the input material. It usually contains higher levels of most of the mineral elements, which are in available forms than the parent material (Edwards and Bohlen, 1996). Vermicompost improves the physical, chemical and biological properties of soil (Kale, 1998). There is a good evidence that vermicompost promotes growth of plants (Lalitha et al., 2000) and it has been found to have a favourable influence on all yield parameters of crops like wheat, paddy and sugarcane (Ismail, 2005). 
Vermiculture is the culture of earthworms and vermicast is the fecal matter released by the earthworms (Ismail, 2005). Many agricultural industries use compost, cattle dung and other animal excreta to grow plants. In today's society, we are faced with the dilemma of getting rid of waste from our industries, household etc. In order for us to practice effective waste management we can utilize the technology of vermicomposting to effectively manage our waste. This process allows us to compost the degradable materials and at the same time utilize the products obtained after composting to enhance crop production and eliminate the use of chemical fertilizers. As indicated by Ansari and Ismail (2001), the application of chemical fertilizers over a period has resulted in poor soil health, reduction in produce, and increase in incidences of pest and disease and environmental pollution. In order to cope with these trenchant problems, the vermin-technology has become the most suitable remedial device (Edwards and Bohlen, 1996; Kumar, 2005).

\subsection{Vermiwash}

Vermiwash is a liquid that is collected after the passage of water through a column of worm action and is very useful as a foliar spray. It is a collection of excretory products and mucus secretion of earthworms along with micronutrients from the soil organic molecules. These are transported to the leaf, shoots and other parts of the plants in the natural ecosystem. Vermiwash, if collected properly, is a clear and transparent, pale yellow coloured fluid (Ismail, 1997). Vermiwash, a foliar spray, is a liquid fertilizer collected after the passage of water through a column of worm activation. It is a collection of excretory and secretory products of earthworms, along with major micronutrients of the soil and soil organic molecules that are useful for plants (Ismail, 1997). Vermiwash seems to possess an inherent property of acting not only as a fertilizer but also as a mild biocide (Pramoth, 1995).

\section{Conclusion}

Environmental Hazards are compounded by accumulation of organic waste from different sources like domestic, agricultural and industrial wastes that can be recycled by improvised and simple technologies. Vermicompost could be effectively used for the cultivation of many crops and vegetables, which could be a step towards sustainable organic farming. Such technologies in organic waste management would lead to zero waste techno farms without the organic waste being wasted and burned rather then would result in recycling and reutilization of precious organic waste bringing about bioconservation and biovitalization of natural resources.

\section{References}

Alban, D. H. and Berry, E. C. 1994. Effects of earthworm invasion on morphology, carbon and nitrogen of forest soil. Appl. Soil Ecol., 1: 243- 249.

Ansari, A. A and S. A. Ismail. 2001a. Vermitechnology in Organic Solid Waste Management. Journal of Soil Biology and Ecology 21:21-24.

Ansari, A. A. and Ismail, S. A. 2001b. A Case Study on Organic Farming in Uttar Pradesh. Journal of Soil Biology and Ecology. 27: 25-27.

Ansari, A. A and Ismail, S. A. 2008. Reclamation of sodic soils through Vermitechnology. Pakistan Journal of Agricultural Research, Volume 21, Number (1-4): 92-97. 
Ansari, A. A and Sukhraj, K. 2010. Effect of vermiwash and vermicompost on soil parameters and productivity of okra (Abelmoschus esculentus) in Guyana. Pakistan Journal of Agricultural Research, Volume 23 Number (3-4): 137-142.

Baker, G. H., Barret, V. J., Gray-Gardner, R. and Buckerfield, J.C. 1992. The life history and abundance of the introduced earthworms Aporrectodea trapezoides and Aporrectodea caliginosa in pasture soils in the Mount Lofty Range, South Australia. Aust. J. Ecol., 17: $177-188$.

* Bouché, M. B., 1971. Relations entre les structures spatiales et fonctionelles des écosystemes, illustrées par le rôle pédobiologique des vers de terre, In: La Vie dans les Sols, Aspects Nouveaux, Études Experimentales, (Pesson, P. ed.), Gauthier-Villars, Paris. pp: 187-209.

Bouché, M. B., 1977. Strate'gies lombriciennes. In: Soil organisms components of ecosystems. (Lohm, U., and Persson, T. eds.), Biol Bull., Stockholm, 25: 122-132.

* Bouché, M. B., 1983. Ecophysiologie des lombriciens: Acquis récentes et perspectives In: New trends in soil biology. (Leprun, Ph., André, H. M., de Medts, A., Grégoire-Wibo, C. and Wauthy, G. eds.), pp: 321-333.

Boyle, K. E., Curry, J. P. and Farrell, E. P. 1997. Influence of earthworms on soil properties and gross production in reclaimed cutover peat. Biol. and Fertil. Soils., 25: 20-26.

Butt, K. 1999. The effect of temperature on the intensive production of Lumbricus terrestris (Oligochaeta: Lumbricidae). Pedobiologia., 35: 257-264.

Butt, K. R., Fredrickson, J., Morris, R. M. and Edwards, C. A. 1997. The earthworm inoculation unit technique: an integrated system for cultivation and soil-inoculation of earthworms. Soil Biol. Biochem., 29: 251-257.

Chalasani, D., Krishna, S. R., Reddy, A. V. S. and Dutt. C. 1998. Vermiculture biotechnology for promoting sustainable agriculture. Asia Pacific Journal of Rural Development., 8: 105-117.

Darwin, C., 1881. The formation of vegetable mould through the action of worms, with observations on their habitats. Murray, London. 326 pp.

Decaens, T., Jimenez, J. J., Lavelle, P., Diaz-Cosin, D. J., Jesus, J. B., Trigo, D. and Garvin, M. H. 1999. Effect of exclusion of the anecic earthworm Martiodrilus carimaguensis Jimenez and Moreno on soil properties and plant growth in grasslands of the eastern plains of Colombia. $6^{\text {th }}$ International Symposium on Earthworm Ecology, Vigo, Spain, Pedobiologia., 43 (6): 835-841.

Doube, B. M., Schimdt, O., Killham, K. and Correll, R. 1997. Influence of mineral soil on the palatability of organic matter for the lumbricid earhtworms: A simple food preference study. Soil. Biol. Biochem., 29: 569-575.

Edwards, C. A. 1982. Production of earthworm protein for animal feed from potato waste. In: Upgrading waste for feed and food. (Ledward, D. A., Taylor, A. J. and Lawrie, R. A. eds.), Butterworths, London.

Edwards, C. A. 1988. Breakdown of animal, vegetable and industrial organic waste by earhtworms. Agric. Ecosyst. Environ., 24: 21-31.

Edwards, C. A. and Bohlen, P. J. 1996. Biology and ecology of earthworm. (3rd edn.), Chapman and Hall, London. 426 pp.

Edwards, C. A. and Lofty, J. R. 1972. Biology of earthworms. Chapman \& Hall, London. 283 pp.

Edwards, C. A., Bohlen, P. J., Linden, D. R. and Subler, S. 1995. Earthworms in agroecosystems. In: Earthworm Ecology and Biogeography in North America. (Hendrix, P. F. eds.), Lewis Publisher, Boca Raton, FL, pp: 185-213.

Grant, W. C. 1955. Studies on moisture relationships in earthworms. Ecology., 36: 400-407. 
Haynes, R. J., Fraser, P. M., Tregutha, R. J., Piercy, J. E., Diaz-Cosin, D. J., Jesus, J. B., Trigo, D. and Garvin, M. H. 1999. Size and the activity of the microbial biomass and N, S and $\mathrm{P}$ availability in earthworm casts derived from arable and pastoral soil amended with plant residues. 6 $6^{\text {th }}$ International symposium on Earthworm Ecology., Vigo, Spain. Pedobiologia., 43: 568-573.

Ismail, S. A. 1993. Keynote Papers and Extended Abstracts. Congress on traditional sciences and technologies of India, I.I.T., Mumbai. 10: 27-30.

Ismail, S. A. 1997. Vermicology: The Biology of Earthworms. Orient longman Press, Hyderabad. $92 \mathrm{pp}$.

Ismail, S.A., 2005. The Earthworm Book. Other India Press, Mapusa, Goa. 101p.

Jairajpuri, M. S. 1993. Earthworms and vermiculture: an introduction. In: Earthworm resources and vermiculture, ZSI, Kolkata, India. pp: 1-5.

Kale, R. D. 1998. Earthworm Cinderella of Organic Farming. Prism Book Pvt Ltd, Bangalore, India. $88 \mathrm{pp}$.

Kale, R. D., Bano, K. and Krishnamoorthy, R. V. 1982. Potential of Perionyx excavatus for utilising organic wastes. Pedobiologia., 23 : 419-425.

Krishnamoorthy, R. V. and Vajranabhaiah, S. N. 1986. Biological activity of earthworm casts: An assessment of plant growth promoter levels in the casts. Proc. Indian Acad. Sci.( Anim. Sci.)., 95: 341-351.

Kumar, A. 2005. Verms and Vermitechnology. Vedams eBooks (P) Ltd, New Delhi India. pp. 110-034

Lachnicht, S. L. and Hendrix, P. F. 2001. Interaction of earthworm Diplocardia mississippiensis (Megascolecidae) with microbial and nutrient dynamics in subtropical Spodosol. Soil Biol. Biochem., 33: 1411-1417.

Lalitha, R., Fathima, K. and Ismail, S. A. 2000. Impact of biopesticides and microbial fertilizers on productivity and growth of Abelmoschus esculentus. Vasundhara The Earth., 1 \& 2: 4-9.

Lavelle, P. 1992. Conservation of soil fertility in low-input agricultural systems of the humid tropics by manipulating earthworm communities (macrofauna project). European Economic Community Project No.TS2-0292-F (EDB).

Lavelle, P. and Martin, A. 1992. Small scale and large scale effects of endogeic earthworms on soil organic matter dynamics in soil of the humid tropics. Soil Biol. Biochem., 24: 1491-1498.

Lavelle, P., Rangel, P. and Kanyonyo, J. 1983. Intestinal mucus production by two species of tropical earthworms: M. lamtoniana and P. corethrurus. In: New Trends in Soil Biology, (Lebrun, $P$. eds.), Dieu-Brichart Press, Louvain le Neuve, Belgium, pp: 405-410.

Lee, K. E. 1983. The influence of earthworms and termites on soil nitrogen cycling. In: New trends in Soil Biology. (Lebrun, P. H., Andre, H. M., de Medts, A., Gregoire-Wibo, C. and Wathy, G. eds.), pp: 35-48.

Lee, K. E. 1985. Earthworms: Their ecology and relationships with soils and land use. Academic Press, Sydney. 411 pp.

Lee, K. and Foster, R. C. 1991. Soil fauna and soil structure. Aust. J. Soil Res., 29: 745-776.

Livan, M. A and W. Thompson. 1997. NARI Annual Report.

Martin, A. 1991. Short- and long-term effects of the endogeic earthworm Millsonia anomala (Omodeo) (Megascolecidae, Oligochaeta) of tropical savannas on soil organic matter. Biol. Fertil. Soils., 11: 234-238.

Muyima, N. Y. O., Reinecke, A. J. and Viljoen-Reinecke, S. A. 1994. Moisture requirements of Dendrobaena veneta- a candidate for vermicomposting. Soil Biol. Biochem., 26: 973-976. 
Nooren, C. A. M., Van Breeman, N., Stoorvogel, J. J. and Jongmans, A. G. 1995. The role of earthworms in the formation of sandy surface soils in a tropical forest in Ivory Coast. Geoderma., 65: 135-148.

Piearce, T. G., Oates, K. and Carruthers, W. J. 1990. A fossil earthworm embryo (Oligochaeta) from beneath a late bronze age midden at Potterna, Wiltshire, UK. J. Zool. Land., 220: 537-542.

Pramoth, A. 1995. Vermiwash-A potent bio-organic liquid "Ferticide". M.Sc., dissertation, University of Madras. 29 pp.

Reddy, M. V. and Pasha, M. 1993. Influence of rainfall, temperature and some soil physicochemical variables on seasonal population structure and vertical distribution of earthworms in two semi- and tropical grassland soils. Int. J. Biotech., 37: 19-26.

Satchell, J. E. 1983. Earthworm microbiology. In: Earthworm ecology: From Darwin to Vermiculture. (Satchell, J. E. ed.), Chapman and Hall, London, UK. pp: 351-364.

Shipley, A. E. 1970. In: The Cambridge Natural History. (Harmer, S. F. and Shipley, A. E. eds.). Codicote, England.

Shuster, W. D., Subler, S. and McCoy, E. L. 2000. Foraging by deep-burrowing earthworms degrades surface soil structure of a fluventic Hapludoll in Ohio. Soil $\mathcal{E}$ Tillage Research., 54: 179-189.

Staaf, H. 1987. Foliage litter turnover and earthworm populations in three beech forests of contrasting soil and vegetation types. Oecologia., 72: 58-64.

Tomlin, A. D., Shipitalo, M. J., Edwards, W. M. and Protz, R. 1995. Earthworms and their influence on soil structure and infilteration. In: Earthworm ecology and biogeography in North America. (Hendrix, P.F. ed.), Lewis Publishers, Chelsea. pp: 159-184.

Valle, J. V., Moro, R. P., Garvin, M. H., Trigo, D. and Diaz Cosin, D. J. 1997. Annual dynamics of the earthworms Hormogaster elisae (Oligochaeta, Hormogastridae) in Central Spain. Soil Biol. Biochem., 29: 309-312.

Wood, T. G. 1974. The distribution of earthworms (Megascolecidae) in relation to soils, vegetation and altitude on the slopes of Mt. Kosciusko, Australia. J. Anim. Ecol., 43: 87-106.

* Not referred directly 


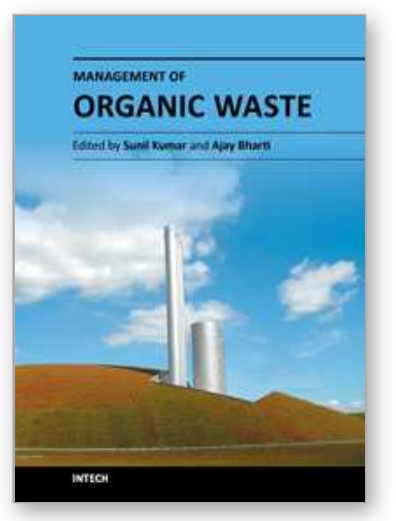

\author{
Management of Organic Waste \\ Edited by Dr. Sunil Kumar
}

ISBN 978-953-307-925-7

Hard cover, 198 pages

Publisher InTech

Published online 01, February, 2012

Published in print edition February, 2012

This book reports research on the utilization of organic waste through composting and vermicomposting, biogas production, recovery of waste materials, and the chemistry involved in the processing of organic waste under various processing aspects. A few chapters on collection systems and disposal of wastes have also been included.

\title{
How to reference
}

In order to correctly reference this scholarly work, feel free to copy and paste the following:

A. A. Ansari and S. A. Ismail (2012). Earthworms and Vermiculture Biotechnology, Management of Organic Waste, Dr. Sunil Kumar (Ed.), ISBN: 978-953-307-925-7, InTech, Available from:

http://www.intechopen.com/books/management-of-organic-waste/earthworms-and-vermiculture-biotechnology

\section{INTECH}

open science | open minds

\section{InTech Europe}

University Campus STeP Ri

Slavka Krautzeka 83/A

51000 Rijeka, Croatia

Phone: +385 (51) 770447

Fax: +385 (51) 686166

www.intechopen.com

\section{InTech China}

Unit 405, Office Block, Hotel Equatorial Shanghai

No.65, Yan An Road (West), Shanghai, 200040, China

中国上海市延安西路65号上海国际贵都大饭店办公楼405单元

Phone: +86-21-62489820

Fax: $+86-21-62489821$ 
(C) 2012 The Author(s). Licensee IntechOpen. This is an open access article distributed under the terms of the Creative Commons Attribution 3.0 License, which permits unrestricted use, distribution, and reproduction in any medium, provided the original work is properly cited. 